\title{
Transitory Urban Interventions for Effective Place making in Shopping Streets: Case of Pettah in Sri Lanka
}

\author{
Janaka Wijesundara, Narmada Wijekoon \\ Department of Architecture, \\ University of Moratuwa, Sri Lanka
}

\begin{abstract}
Asian cities possess a unique heterogeneity of social and cultural backgrounds, which have significant informal sectors with open temporary and mobile activities that are flexible, quick, light and low-cost. Today, the mobile, temporary and bazaar type informal activities command an increasing demand as an alternative to the high urban rental land and goods.
\end{abstract}

The study explores the temporary urban interventions such as activity-based intentions, structural interventions and sensory interventions in urban shopping streets as place making elements. This stimulates the city to be a unique place for people and transforms it into a place of enjoyment. It can be remarkably effective in remaking an urban public place such as Pettah in Colombo city.

Permanent physical components are resources to improve shopping streets rather than temporary components. That is because city development processes assume that improvements in temporary urban interventions cause uncertain risks in the city. Therefore, temporary components in streetscapes receive less attention and care. Resources are committed for permanent physical improvements of shopping streets by replacing or removing the temporary installations. This is despite the great interest people show for these places and the benefits gained from them.

The research confirms that the temporary urban interventions in shopping streets are the key aspects that make the urban places active. The hierarchy and continuity in the arrangement of layers creates urban order, which may not be understood by an outsider of that spatial culture. Using unique patterns to enhance city identity and image is also a strategy of economic and community development in the city. Place-making brings positive results in empowering community capacity. It also reveals elements for the affordable places given by the community.

Keywords: Urban place, shopping streets, temporary urban interventions, placemaking, Pettah, Colombo 


\section{Introduction}

Most Asian cities have highly dense population of consumers and visitors in streets where agglomeration of activities exists to cater for everyday needs of people. In highly urbanized cities, streets are the origin of dynamic commercial activities and have become the culmination of city infrastructure because of its flexibility to replicate facilities, social interactions and economy of people. That is because most of the informal shopping activities, bazaar type open commercial activities, temporary and mobile activities are established around the multiple needs of people.

Shopping streets as the heart of Pettah are the first phase of livable and authentic development of Colombo. Therefore, effective making of commercial streets is the way to improve the quality of place with concentration of activities and many amenities over a period of time. These quality-shopping streets have a strong sense of place. Therefore, throughout the study, characteristics and strategies of quality shopping streets are explored. That is because revitalizing shopping streets will enable interaction between different types of people and they will be guided appropriately.

For the commercial/ shopping backgrounds, unique qualities are required to accomplish particular needs of selling goods, which can be identified as tactical methods of shopping. (Mehrothra, 2007) elaborates the idea of temporal landscape, kinetic city or everyday urbanism as a universal relevance for contemporary urban conditions. In fact, street culture and bazaar naturally get unsettled and discontented. People who continue with the everyday city routine have enhanced this unpredictable kinetic atmosphere.

According to the observations, small-scale, improvements are progressively achieving the short-term commitment of place and economy. Hence, the owners themselves achieve these short-term improvements through temporary urban interventions, which are generally additions and extensions to built fabric or context. These temporary urban interventions in shopping streets lead as a catalyst for effective community development, economic improvement, cultural enhancement and infrastructure upgrade, while promoting a strong sense of place to maximize quality of place, life and amenities around people.

\section{Research Question}

In shopping streets, temporary urban interventions are competitive in attracting people and retaining vital, vibrant and livable communities. However, the general practice is that the policy makers understandably commit resources on permanent physical improvements of shopping streets by replacing or removing the temporary installations. This is done under the assumption that temporary interventions cause uncertain risks rather than committing resources on permanent improvements for streets. Therefore, it is important to reassess the existence of temporary urban interventions and its levels of contribution to the place making process. This deals with the research question of what and how the temporary urban interventions contribute to the process of making places in Pettah. 
The research focuses on the tactical place making in shopping streets, which is basically about creating and transforming places into where people want to linger and enjoy a particular activity with amenities of place, while creating place through temporary interventions that result in lighter, quicker, cheaper place making.

\section{Place-making in terms of shopping environments (What)}

Most Asian commercial cityscapes consist of unique patterns and different functional layers such as permanent, temporary, mobile and open spaces. These layers are enriched with diverse potentials creating the place according to its particular function. According to (Mehrothra, 2007) in Asia and in cities of South Asia in particular, 'tidiness' is not as much of a concern as in the cities of the West. Architects, planners, and urban designers are concerned about the organization of human activities in space. Also, in Asia when someone tidies up a street by paving public sidewalks or cleaning encroachment - through their efforts of cleaning up the kinetic city, they become urban heroes. In the Sri Lankan context, the same character has been enhanced in commercial environments.

Place-making is 'the process of creating quality of places that people want to live work and learn in' (Wyckoff, 2014). But in shopping streets, place making strengthens the connection and interaction between people and place while shaping the physical environment in order to maximize the capacities of local community asserts. It is further improved by facilitating creative patterns of use, paying particular attention to the physical, cultural, and social identities that define a place and support its ongoing evolution.

Place-making is relevant and powerful in enhancing the quality of life and supporting collaboration that connects people and supports local action. (MIT Department of Urban Studies and Planning, 2013). Also, it is a process that benefits the people who share it on a daily, weekly \& yearly routine and recognizes relationships that nurture community capacity on a long-term period. Moreover, (Markusen \& Gudwa, 2010) state creative place making animates public and private spaces, rejuvenates structures and streetscapes, improves the local business viability and public safety while bringing different people together to celebrate, enjoy and get inspired. It explains the benefits related to the making of place and economic developments and higher property values for the community.

Comprehensive series of activity patterns based shopping streets are mentors for a powerful change and evolution of urban shopping streets, which provides opportunities for a sustainable city. Different layers of street such as permanent, temporary and moving have number of potentials to attract people and create inviting spaces. Therefore, to uplift the quality of places that contributes to the people's happiness and well being, it is necessary to bring social, cultural and environmental potentials together. 


\section{Benefits of place-making}

Place-making is an innovative way of shaping the community and creating attractive, sustainable places. Though this is the scope of place making process, outcomes are vital in actions. Value assessing is as important as engaging with the particular kind of concept for the people, place, and community. Place-making process also considers reducing risks. In the study of creative place making, Vazquez (2012) elaborates that,

- Creative retail shopping activities can provide high revenues on investment for both community and economic development.

- Place-making enhances the creative economy, which provides more entryways for the prosperity of individuals and communities.

- Place-making can help communities to be flexible for changes, and make their communities more sustainable.

- Place-making strives to balance two conflicting needs of individuals in society - self-actualization and safety.

- Place-making can uplift product quality and product based communities in society.

\section{Temporary urban interventions in shopping streets}

Places are for people and should be flexible for various functions and changes in relation to its components. Temporary interventions have a potential of adding activity and enhancing existing activities to these shopping streets, which will provide new opportunity for regenerating the place and its use.

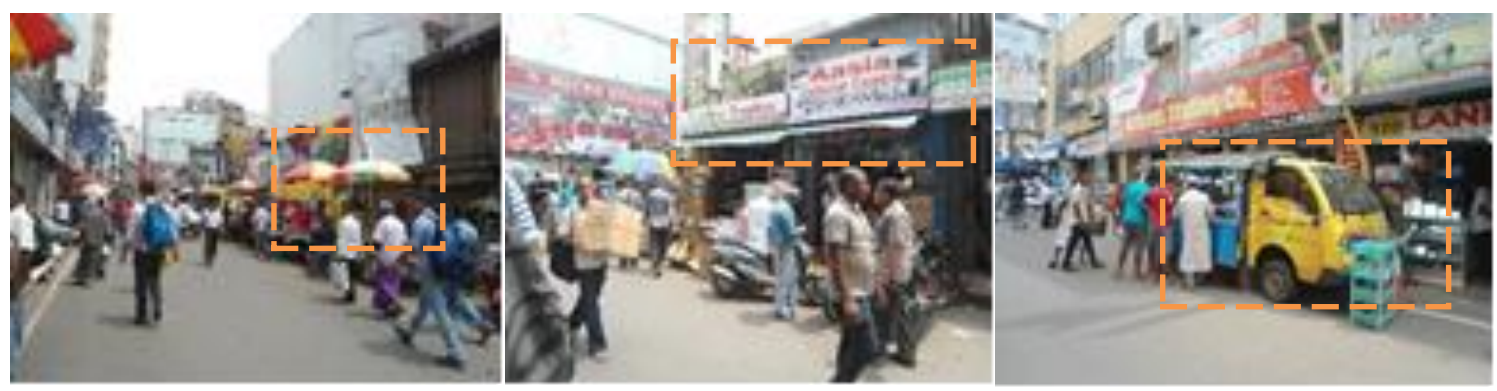

Fig. 01- Temporary urban interventions in Pettah Source: Author

\subsection{Activity based interventions}

Seasonal activities, promotional activities, bazaar type activities, pop-up activities, caravans are observed examples for activity based temporary urban interventions in shopping streets in Sri-Lankan context. 


\subsection{Structural interventions}

Examples for structural interventions from existing structures around the world can be stated as billboards, name boards, public notices boards, seating arrangements, illuminations, flags, sounds, canopies, umbrella shadings, shopping decks etc.

\subsection{Sensory interventions}

Sensory interventions in streets are ways of defining places on street using music, different sounds, illuminations, smell, colors, etc. This will transform distinctive presence on the streets into a special one. These sensory interventions increase the intensity of people's emotions. Makes the place unique with perceptible characteristics along streets.

In 2010, Carlo Rousseeuw published Kinetic Architecture; modeling design and behaviour - interactive architecture that interacts with the landscape and structural kinetic changes. Kinetic architecture, the simulation of structure and behaviour play a valuable role, making each structure unique to its context, usage and interaction. He interpreted light levels, temperature, proximity creates uniqueness to a structure and context, while noise levels, smell, views, and shadings provide favourable conditions to stay, spend time and move around on a daily basis.

\section{Different approaches to place making in shopping environments}

\section{$3.1 \quad$ Lighter, quicker, cheaper approach}

Lighter, quicker, cheaper approach involves making temporary interventions challenging towards the high value of urban setting and provides benefits for people to target the shopping streets. These temporary activities mainly characterized by flexibility and adaptability, can be easily replicated because it is subjected to necessary changes. This is a classic method of tackling people to their place who has respect for dynamic and variety of place and goods while expecting cheaper stuff. Therefore, such approach is appealing not only because they are relatively cheap but also because it's quick to implement. In relation to quick implementation, experiments can be done to evaluate the growth of small business, start-ups, and local entrepreneurship as a futuristic approach to urban planning. Shopping streets nurtures joy while addressing the safety and security of rapidly urbanizing city's large population.

\subsection{Out-of-the-box approach}

The out-of-the-box approach is also an elevation of temporary urban interventions for making the place effectively. Activities do not stick to the particular structure and place. This approach meant to achieve the place where most of the assets are magnetic to one particular area. The modular, multi functional docks are light in weight and are easier to assemble and encourage people to interact with shopping streets in new ways (Public spaces, 2016). 


\subsection{Hands-on approach}

Unlike the aforementioned two approaches, this is of learning and experimenting new cultures of temporary activities in public places. A hands-on approach also has the vision to facilitate benefit for community-building and empowering public places.

\section{Selected architectural parameters to measure place-making in shopping streets}

\begin{tabular}{|l|l|}
\hline 1) Spatial anthropology study & 2) Social anthropology study \\
\hline Usage and activity & Sociability \\
\hline 1. Local business & $\begin{array}{l}\text { 10. Street life } \\
\text { 2. Land use }\end{array}$ \\
$\begin{array}{l}\text { 3. Retail sales Rent values } \\
\text { Comfort and image }\end{array}$ & $\begin{array}{l}\text { 12. Evening usage } \\
\text { 4. Crime }\end{array}$ \\
5. Protection from weather & \\
6. Movement of people & \\
Access and linkage & \\
7. Street edge activities & \\
8. Transit usage & \\
9. Human traffic & \\
\hline
\end{tabular}

\section{Methodology}

\section{Pettah}

Today, Pettah is famous for its open markets, bazaars and shopping streets with a busy vehicular and individual movement. People respects shopping in Pettah because, of the availability and affordability of various goods and services in relation to high urban rental of the place. These streets are the generators of commercial diversity, variety in activities and different form of urban components due to the specialization of function.

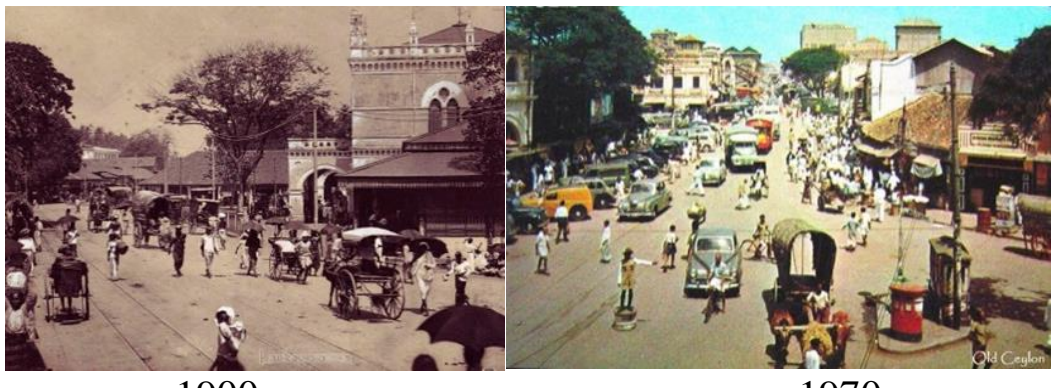

1900
1970

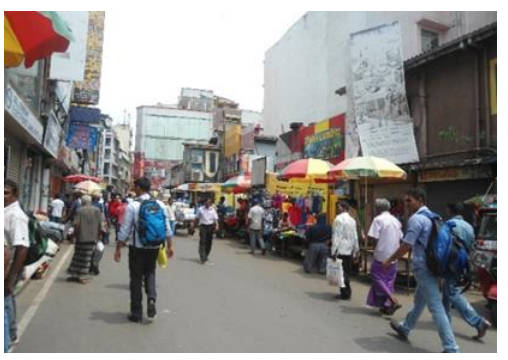

2016

Fig. 02- Pettah

Source: Old Ceylon and Author 


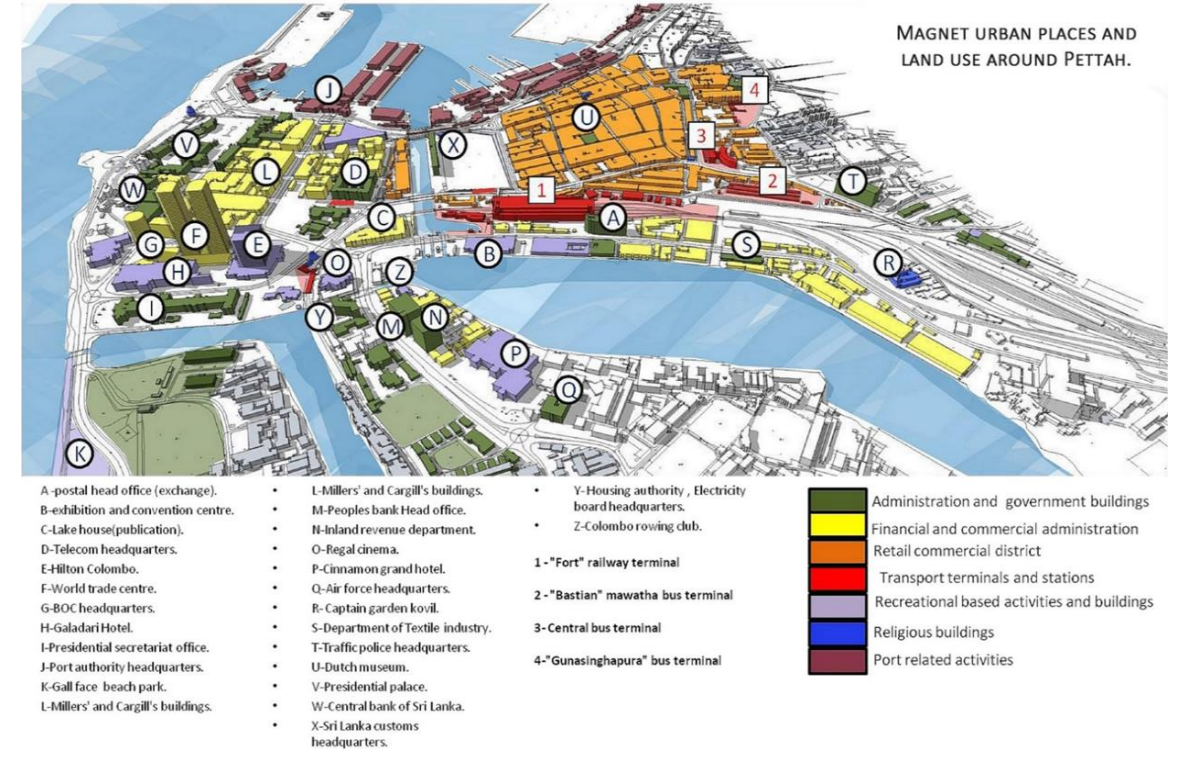

Fig 3- Magnet urban places and land use around Pettah, 2015

Source: Supun De Silva, University of Moratuwa

\section{Research stages}

Table 1- Research stages

\begin{tabular}{|c|c|}
\hline Stage & Methodological steps \\
\hline \multirow[t]{2}{*}{$\begin{array}{l}01 \\
\text { (quantitative research) }\end{array}$} & $\begin{array}{l}\text { - Identifying man made place making elements in shopping streets in Pettah } \\
\text { with selected factors (based on the theoretical background) }\end{array}$ \\
\hline & - Analyzed through street mapping. Observations, counting data \\
\hline \multirow{4}{*}{ (qualitative research) } & - Studying and onsite observing in selected streets \\
\hline & - Identifying level of place-making in shopping streets through evaluation chart. \\
\hline & $\begin{array}{l}\text { - Capture the spatial and social anthropological properties to make the street } \\
\text { effective and quality of place is accessed and most functioning place making } \\
\text { urban interventions in shopping streets. }\end{array}$ \\
\hline & $\begin{array}{l}\text { - Identify the level of sustainability in shopping streets in order to signify } \\
\text { temporary urban interventions. }\end{array}$ \\
\hline
\end{tabular}

\subsection{Quantitative research -Mapping Street - stage one}

Mapping streets is the tool to identify different types of urban interventions in shopping streets and to make the place effective in terms of shopping function. Three streets were studied in order to understand 'where place-making is created?' and 'what are the temporary urban interventions helps to make the street live and effective'. Data was collected under street layer studies. Namely, public commentaries, objects scale and activity patterns.

1) Analyzing layers of shopping Street-

Especially shopping streets are made with various layers, which reveal the hidden

life of the streets. Shopping streets in Pettah are lined on the edges with temporary 
stalls, installations, and mobile activities. Activities and movement occur parallel to streets here.

2) Mapping temporary urban interventions-

Sounds define spaces on the street. In a tropical climate, trees, canopies, extensions of building porches and shadows define cool zones, especially in shopping streets. This thermal reprieve cause changes in street continuously.

\section{3) Mapping activity patters in selected streets-}

Activities in streets are specific according to particular function. Also, movement and flows of pedestrian and vehicles have a particular rhythm. Counting surveys were conducted to map the pedestrian and vehicular flows in each selected street.

\section{4) Mapping pedestrian flow of the selected shopping streets}

\section{5) Gather text and commentaries about street - (The street as text (ure))}

This is to capture the spirit of the street through an experiential mapping represented by the text and commentary by users. Relevant shopping street is deconstructed graphically through signage, snatches of conservation, emotions, personal thoughts, commentaries, and queries.

\section{6) Analyzing Components of scale-}

Streets face drastic changes in the scale of the urban fabric. Different sizes of commercial allotments have an impact on the street and pedestrian who tend to perceives the changes through the dynamic rhythm of the walkway arcades (Limin $\mathrm{H}, 2001)$

Table 2 - study method of shopping streets in terms of urban intervention types

\begin{tabular}{|c|c|c|c|c|}
\hline \multicolumn{2}{|l|}{ data } & \multirow[t]{2}{*}{ Type of Data collection } & \multirow{2}{*}{$\begin{array}{l}\text { Data } \\
\text { collective } \\
\text { tools }\end{array}$} & \multirow[t]{2}{*}{ Data presenting } \\
\hline form & type & & & \\
\hline permanent & Structural & Analyzing layers of shopping Street & $\begin{array}{l}\text { Photograph } \\
\text { y survey }\end{array}$ & Activity map \\
\hline \multirow[t]{4}{*}{ temporary } & \multirow[t]{3}{*}{$\begin{array}{l}\text { Activity } \\
\text { based }\end{array}$} & $\begin{array}{l}\text { Mapping temporary urban } \\
\text { interventions }\end{array}$ & Counting & \multirow{5}{*}{$\begin{array}{l}\text { Area map colored } \\
\text { with } \\
\text { morphological } \\
\text { patterns }\end{array}$} \\
\hline & & $\begin{array}{l}\text { Mapping activity patters in selected } \\
\text { streets }\end{array}$ & & \\
\hline & & $\begin{array}{l}\text { Mapping pedestrian flow of the } \\
\text { selected shopping streets }\end{array}$ & & \\
\hline & \multirow[t]{2}{*}{ Sensory } & $\begin{array}{l}\text { Gather text and commentaries about } \\
\text { street }\end{array}$ & $\begin{array}{l}\text { Location } \\
\text { survey }\end{array}$ & \\
\hline mobile & & Analyzing Components of scale & $\begin{array}{l}\text { Observatory } \\
\text { survey }\end{array}$ & \\
\hline
\end{tabular}


Table 3- Identified urban interventions in shopping streets in terms of physical form of Pettah, Colombo

\begin{tabular}{|c|c|c|c|}
\hline Physical form & structural & activity based & sensory \\
\hline permanent & $\begin{array}{l}\text { Billboards } \\
\text { Name boards } \\
\text { Public notices boards } \\
\text { Seating arrangements } \\
\text { Canopies }\end{array}$ & & \\
\hline temporary & $\begin{array}{l}\text { Illuminations } \\
\text { Flags } \\
\text { Sounds } \\
\text { Umbrella shadings } \\
\text { Shopping decks }\end{array}$ & $\begin{array}{l}\text { Seasonal activities } \\
\text { Bazaar types activities } \\
\text { Informal activities }\end{array}$ & $\begin{array}{l}\text { Sounds } \\
\text { Illumination } \\
\text { Smell }\end{array}$ \\
\hline mobile & & $\begin{array}{l}\text { Pop-up activities } \\
\text { Promotional activities } \\
\text { Caravans } \\
\text { Mobile carts }\end{array}$ & \\
\hline
\end{tabular}

\subsection{Qualitative research on 'what creates place-making in shopping streets - Stage Two}

Table 4- research protocol

\begin{tabular}{|l|l|}
\hline $\begin{array}{l}\text { Aims and } \\
\text { objectives }\end{array}$ & $\begin{array}{l}\text { - Identify key components of temporary urban interventions that reinforce the } \\
\text { quality of shopping streets. }\end{array}$ \\
- Examine strategies of using temporary urban interventions to create magnetic \\
effect on people. \\
- Access characteristics of a quality shopping street impact on form, function, user \\
and community. \\
- Define positive matrix of tactical place making in shopping streets to create strong \\
sense of place.
\end{tabular}




\begin{tabular}{|c|c|c|}
\hline $\begin{array}{l}\text { (selection } \\
\text { criteria) }\end{array}$ & \multicolumn{2}{|c|}{$\begin{array}{l}\text { people each- random individuals) each one was provided both written and } \\
\text { photography questionnaires. }\end{array}$} \\
\hline $\begin{array}{l}\text { Data } \\
\text { collecting } \\
\text { instruments/ } \\
\text { tool }\end{array}$ & \multicolumn{2}{|c|}{$\begin{array}{l}\text { - Activity based characteristics are supported by the observations and photographic } \\
\text { surveys. } \\
\text { - Informal interviews with users of streets strengthen the responses on structural } \\
\text { urban interventions as well as activity-based interventions in selected cases in } \\
\text { Pettah, Colombo. } \\
\text { - The questionnaire survey and photography questionnaire survey sessions. } \\
\text { - Counting surveys were conducted. Movements of people were recorded in } \\
\text { selected streets using an area map. Finally, activity maps, maps for flow of people, } \\
\text { maps for movements of people, human traffic maps have been produced based on } \\
\text { the counting survey. } \\
\text { - Personal communications aided the observations towards more practical } \\
\text { situations. }\end{array}$} \\
\hline \multirow{16}{*}{$\begin{array}{l}\text { Analyzing } \\
\text { data }\end{array}$} & \multicolumn{2}{|c|}{ 1. Assess the components of a quality of place } \\
\hline & Key attributes & Method of analysis \\
\hline & \multirow[t]{3}{*}{ User and activity } & Mapping components of streets \\
\hline & & Statics of build environment components \\
\hline & & Mapping pedestrian flow \\
\hline & \multirow{4}{*}{$\begin{array}{l}\text { Comfort and } \\
\text { image }\end{array}$} & Street as text(ure) \\
\hline & & Mapping thermal reprieve of the street \\
\hline & & Mapping diversity of soundscape in the street \\
\hline & & Mapping the movement of people \\
\hline & \multirow[t]{3}{*}{ Access and linage } & Mapping activity based intervention \\
\hline & & Mapping accessibility \\
\hline & & Mapping human traffic \\
\hline & \multirow[t]{3}{*}{ sociability } & observation \\
\hline & & Formal informal interviews \\
\hline & & Personal experience \\
\hline & \multicolumn{2}{|c|}{$\begin{array}{l}\text { 2. Quality of streets - Evaluation chart } \\
\text { 3. Kevin lynch's performance dimensions - Evaluation chart }\end{array}$} \\
\hline $\begin{array}{l}\text { Data } \\
\text { presentation } \\
\text { techniques }\end{array}$ & \multicolumn{2}{|c|}{$\begin{array}{l}\text { Area maps } \\
\text { Plans and sections } \\
\text { Photographic analysis } \\
\text { Activity counter maps and charts }\end{array}$} \\
\hline $\begin{array}{l}\text { Scope and } \\
\text { Limitations } \\
\text { of the } \\
\text { method }\end{array}$ & \multicolumn{2}{|c|}{$\begin{array}{l}\text { - The study scope is within the theory of 'tactical place-making' in three selected } \\
\text { shopping streets of Pettah in Colombo. } \\
\text { - The research aims to examine temporary urban interventions in order to creating } \\
\text { quality of shopping streets and strong sense of place with many amenities. } \\
\text { - The study will be focused only on the place-led commercial and community } \\
\text { development strategies in shopping streets. }\end{array}$} \\
\hline
\end{tabular}




\section{Findings}

Quality of place- Summary chart

\begin{tabular}{|c|c|c|c|c|c|c|}
\hline \multirow{2}{*}{$\begin{array}{c}\text { Key } \\
\text { attributes }\end{array}$} & \multirow[t]{2}{*}{ intangibles } & \multicolumn{2}{|c|}{ Data variable } & \multicolumn{3}{|c|}{ Comment for the place } \\
\hline & & No & $\begin{array}{c}\text { measuremen } \\
\text { ts }\end{array}$ & Street 1 & Street 2 & Street 3 \\
\hline \multirow{8}{*}{$\begin{array}{l}\text { User and } \\
\text { activities }\end{array}$} & active & \multirow[t]{2}{*}{01} & \multirow{2}{*}{$\begin{array}{c}\text { Local } \\
\text { business }\end{array}$} & \multirow[t]{2}{*}{ high } & \multirow[t]{2}{*}{ high } & \multirow[t]{2}{*}{ average } \\
\hline & \multirow[t]{2}{*}{ fun } & & & & & \\
\hline & & \multirow[t]{3}{*}{02} & \multirow{3}{*}{ Land-use } & \multirow[t]{3}{*}{ high } & \multirow[t]{3}{*}{ average } & \multirow[t]{3}{*}{ low } \\
\hline & vital & & & & & \\
\hline & \multirow[t]{2}{*}{ special } & & & & & \\
\hline & & \multirow[t]{3}{*}{03} & \multirow{3}{*}{$\begin{array}{c}\text { retail sales } \\
\& \text { rent } \\
\text { values }\end{array}$} & \multirow[t]{3}{*}{ satisfied } & \multirow[t]{3}{*}{ satisfied } & \multirow{3}{*}{$\begin{array}{l}\text { Not } \\
\text { satisfied }\end{array}$} \\
\hline & real & & & & & \\
\hline & useful & & & & & \\
\hline \multirow{4}{*}{$\begin{array}{l}\text { Comfort } \\
\text { and image }\end{array}$} & safe & 04 & Crimes & 10w & low & average \\
\hline & attractive & 05 & $\begin{array}{c}\text { Protection } \\
\text { from } \\
\text { weather }\end{array}$ & satisfied & available & barely \\
\hline & Walkable & \multirow[t]{2}{*}{06} & \multirow{2}{*}{$\begin{array}{l}\text { Movement } \\
\text { of people }\end{array}$} & \multirow[t]{2}{*}{ high } & \multirow[t]{2}{*}{ high } & \multirow[t]{2}{*}{ low } \\
\hline & clean & & & & & \\
\hline \multirow{5}{*}{$\begin{array}{c}\text { Access and } \\
\text { linkage }\end{array}$} & proximity & \multirow[t]{2}{*}{07} & \multirow{2}{*}{$\begin{array}{c}\text { Street edge } \\
\text { activity }\end{array}$} & \multirow[t]{2}{*}{ dynamic } & \multirow[t]{2}{*}{ regular } & \multirow[t]{2}{*}{ freeze } \\
\hline & accessible & & & & & \\
\hline & $\begin{array}{l}\text { readable } \\
\text { connected }\end{array}$ & 08 & $\begin{array}{l}\text { Transit } \\
\text { usage }\end{array}$ & average & average & high \\
\hline & continuity & 09 & Human & high & average & 10w \\
\hline & convenient & & traffic & & & \\
\hline Sociability & diverse & 10 & Street life & dynamic & unique & freeze \\
\hline & neighborly & 11 & Community & high & average & poor \\
\hline & welcoming & & involvement & & & \\
\hline & friendly & 12 & $\begin{array}{l}\text { Evening } \\
\text { usage }\end{array}$ & poor & poor & absent \\
\hline & cooperative & 13 & $\begin{array}{l}\text { Number of } \\
\text { children, } \\
\text { women and } \\
\text { elderly }\end{array}$ & average & high & average \\
\hline
\end{tabular}

Kevin Lynch's Performance dimensions- Evaluation table

\begin{tabular}{|c|c|c|c|c|c|}
\hline \multirow{2}{*}{$\begin{array}{l}\text { Performance } \\
\text { dimensions }\end{array}$} & \multicolumn{2}{|c|}{ Data variable } & \multicolumn{3}{|c|}{ Comment for the place } \\
\hline & No. & measurements & $\begin{array}{c}\text { Street } \\
1\end{array}$ & $\begin{array}{c}\text { Street } \\
2\end{array}$ & $\begin{array}{c}\text { Street } \\
3\end{array}$ \\
\hline \multirow[t]{3}{*}{ vitality } & 02 & Land use & hugh & average & low \\
\hline & 06 & $\begin{array}{c}\text { Movement of } \\
\text { people }\end{array}$ & high & high & low \\
\hline & 12 & Evening usage & poor & poor & absent \\
\hline \multirow[t]{2}{*}{ sense } & 07 & $\begin{array}{c}\text { Street edge } \\
\text { activity }\end{array}$ & dymamic & regular & fireeze \\
\hline & 05 & $\begin{array}{c}\text { Protection from } \\
\text { weather }\end{array}$ & Satisfied & avaslable & barely \\
\hline \multirow[t]{3}{*}{ fit } & 10 & Street life & dyruamic & unique & fireeze \\
\hline & 11 & $\begin{array}{l}\text { Commumity } \\
\text { involvement }\end{array}$ & high & axverage & poor \\
\hline & 13 & $\begin{array}{l}\text { Number of } \\
\text { children, } \\
\text { women and } \\
\text { elderly }\end{array}$ & average & high & average \\
\hline \multirow[t]{2}{*}{ access } & 01 & Local business & high & lugh & average \\
\hline & 08 & Transit usage & average & average & high \\
\hline \multirow[t]{3}{*}{ control } & 03 & $\begin{array}{l}\text { retail sales \& } \\
\text { rent values }\end{array}$ & satisfied & satisfied & $\begin{array}{l}\text { Not } \\
\text { satisfied }\end{array}$ \\
\hline & 04 & Crimes & low & low & average \\
\hline & 09 & Human traffic & high & averape & low \\
\hline
\end{tabular}

Comments for each street on the respective data variable are given 'color grading' as follows. Good (100\%) 

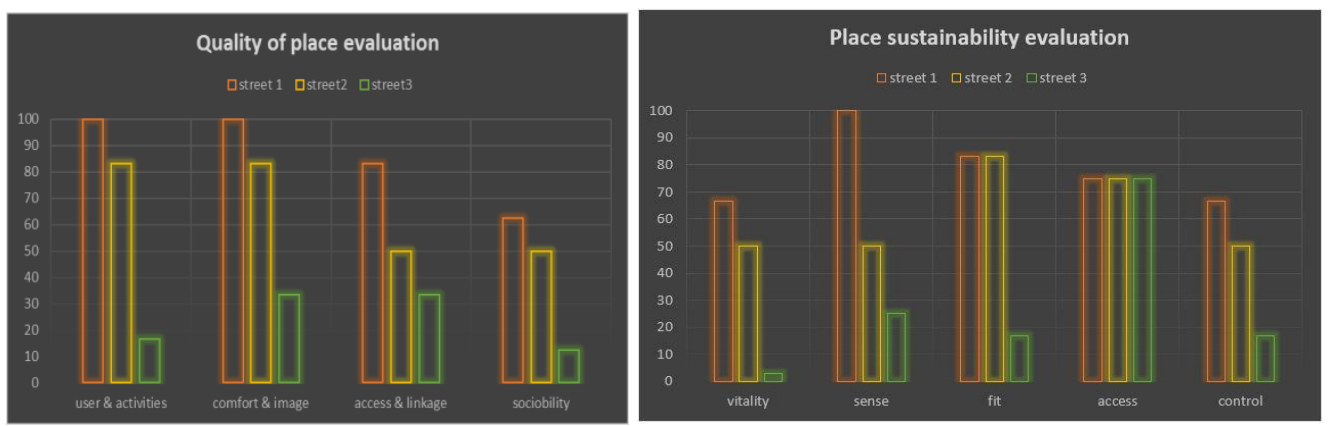

\section{Formation of Place-making}

a. Activity based temporary interventions make long-term changes in shopping streets to its physical form and function.

Short term activity based interventions

Long term change

b.Tactical place making in shopping streets make strong sense of place.

\begin{tabular}{|l|}
\hline \multicolumn{1}{|c|}{ Physical form } \\
Proper mix of land use and activities
\end{tabular}

c. Effective shopping streets obtain characteristics that impact on form, function, user and community

- Human scale of interventions - to familiarize with people

- Walkable - people/ pedestrian oriented

- Density and scale - appropriate to the place and function

- Eye level - easy access and comfort for people

d. Results of these characteristics in shopping streets have potential to become safe, connected, comfortable, social, welcoming, accessibility, authentic, facilitate civic engagement.

\begin{tabular}{|ll|}
\hline Human scale & Safe \\
Walkability & Connected \\
Density, scale & Comfortable \\
Eye level & Sociable \\
Human scale & Welcoming \\
& Accessible \\
& Authentic \\
& Facilitate civic engagement \\
\hline
\end{tabular}


Place making has,

Temporary urban interventions

Activities

Community

People

Responses

Economic

Place making

stage

play

actors

spectators

how you feel

play makes money

is strong if the above are true

Responses on elements of physical form are higher on temporary urban interventions such as activity based, structural and sensory interventions rather than permanent activities/ structures. That is because, these interventions have a strong sense on people and satisfy human scale, walkability and mass, density and scale of place. Result of these three characteristics of temporary urban interventions which confirm safety, comfort, sociability, welcome, accessibility, authenticity of the street facilitate civic engagement of shopping streets as place- led development process of place making.

\section{Remarks and Comments}

a.Temporary urban interventions indicate significance in action and evolution where common generators persist such as transport nodes (fort railway station, bus terminals and scattered bus stops), commuter interchanges, traffic locations, shopping streets ends, functional landmarks etc.

b. Activity based interventions and sensory interventions have great sense for attracting people unlike structural interventions in shopping streets, which have potential to change its properties over the working period of time.

c. Activity based interventions lead to a lighter, quicker, cheaper approach. Sensory interventions and structural interventions lead to branding, signage strategy which improves the visibility, safety and develop festive or celebratory atmosphere to stimulate people and place.

d. Vehicular movements disturb the specific pattern of pedestrian movement and people have respect for free movements especially in shopping streets.

e. These shopping streets are highly active during daytime from 9.00 am to $8.30 \mathrm{pm}$

f. Street width and building heights directly impact people's impression on safety, comfort and confidence of being on shopping streets.

g.Activity based temporary urban interventions stage communities to upgrade their living standards while improving the quality and effective use of urban shopping streets. 


\section{Conclusion}

As the commercial hot spot of Colombo, Pettah draws in consumers and daily visitors maintaining high concentration of population. About 0.6 sq. $\mathrm{km}$ of land extent of Pettah offers thousands of job opportunities and caters for the everyday needs of people, and has the potential to resist the high urban rental of land and goods. Also, it has become a platform for new entrepreneurs/ startups as a response for the rapid development and urbanization. Therefore, high demand for the limited land of Pettah has undertaken its potential to achieve unbearable consequences of rapid development process and urbanization by temporary uses.

Streets in Pettah are as seen everyday places of people. Therefore, streets have a crucial and deep value to make it an effective and lively neighbourhood depending on a local community's assets, inspiration, and potentials. Result of making shopping streets effective and improving their quality upgrades people's health, happiness, and well-being and also it supports to the ongoing evolution of urban public places.

Generally, place making refers to a collaborative, flexible, transformative, dynamic, adaptable and sociable process, which can shape the public domain in order to maximize property values of place. According to the study area, shopping streets consider as the heart of Pettah, which is being, approached a tactical place making (or lighter, quicker, cheaper place making) through temporary urban interventions such as activities, structural and sensory interventions.

Tactical place making, (1) terms an empty, leftover lot or edges on high valued shopping streets into temporary retail stalls (2) allows merchants, entrepreneurs and even food vendors to sell their products. Also, (3) adds low cost, flexible and useful drinks and snacks outlets to refresh people while walking along the streets. (4) Adds and install way finding signage on built fabric and street edges to local businesses and attractions. (5) Works with sounds capes, lightings and smell of foods etc. improves memory of place and identity. Also, (6) provides platform to upgrade community life standards that lead life from streets.

Therefore, the vision on tactical place making evolves into implementing smallscale businesses as place-led development process, which leaves community to revitalize and nurture their future while recreating shopping streets into a key gateway for the sustainable everyday needs and desires.

Research can reveal potential of shopping streets during the study.

$\alpha$. Temporary urban interventions stage the shopping activities, which can resist the high urban rental of highly urbanized streets while stimulating quality of shopping streets. 
$\beta$. Temporary interventions in shopping streets allow local retail business to experiment with new concepts before making a substantial political and financial commitment.

$\chi$. Sensory interventions have high potential to attract people and stimulate shopping atmosphere to improve its quality and effectiveness.

$\delta$. Temporary urban interventions are adapted to fill vacant and neglected urban spaces, which has potential to minimize antisocial activities as a tool for a better future of city.

$\varepsilon$. These temporary interventions have the flexibility to get maximum use of high demanded land. Therefore, it is a great saving of resources that contributes to the transforming city towards a better future.

\section{Future studies}

Research forms a platform to nurture community capacity and creates opportunities for new entrepreneurs, startups and more substantial investment on shopping streets while transforming them into a better future. Based on the research findings of shopping streets in Pettah, further research can be carried out regarding strategic place making or creative place making in (shopping) streets. This is because tactical place making in shopping streets of Pettah is studied in this research.

\section{References}

Agnew, J. (1987). Place and Politics: The Geographical Mediation of State and. London: Allen and Unwin.

Altman I, L. S. (1992). Human behavior and environments: Advances in theory and research. Volume 12. In L. S. Altman I, Place attachment. New York: Plenum Press.

Burcu H. Ozuduru, J. (2013). Retail location and urban. Surveys and Perspectives Integrating Environment and Society: Vol. 6.

Canter, D. (1977). The psychology of place. In D. Canter, The psychology of place (pp. 58-59). London: Architectural Press.

Compassion, C. f. (2015). Charters for compassion. Retrieved from charterforcompassion.org: http://www.charterforcompassion.org/index.php/organizing-processes/what-is-placemaking

Cresswell, T. (2009). Place. Elsevier Inc.

Cushman, W. H. (2016). New York, Hong Kong and Paris are home to world's most expensive shopping streets. http://www.citymayors.com/economics/shopping_streets.html. Retrieved from City Mayors: Most expensive shopping streets: http://www.citymayors.com/economics/shopping_streets.html

E, R. (1973). Phenomenon of place. Toronto: University of Toronto.

F. Erkip, O. K. (2014). Retailers' resilience strategies and their impacts on urban spaces in Turkey. Cities 36, 112- 20.

Ghel, J. (2010). Cities for people. Washinton DC: Island Press.

Halprin, L. (1972). Notebooks. MIT Press.

Hashemnezhad. Hashem, Y. S. (2013). Comparison the concepts of sense of place and attachment to place in Architectural Studies. GEOGRAFIA Online: Malaysia Journal of Society and Space : 9 issue, 107 - 117.

Horne, M. (2014). Temporary use of pop-up environment's potential for repurposing neglected building and spaces. Georgia State University.

Jackson, J. B. (1952). The Almost Perfect Town: Landscape.

Lang, R. (2003). Edgeless Cities: Exploring the Elusive Metropolis. Washington D.C.: The Brookings Institution. 
Limin, H.(2001), Urban Design International, Volume 6, Number 2, 1 June 2001, pp. 65-75(11). Palgrave Macmillan

Lukermann, F. (1964). 'Geography as a formal intellectual discipline and the way in which it contributes to human knowledge'. Canadian geographer, 167-172.

Lynch, K. (1984). a theory of good city form. MIT Press.

Makevita U, R. U. (2013). Ascertaining the kinetic patterns of informal spaces in the commercial streets of Pettah, SriLanka. International Conference on ' City, people and place', 69-88.

Markusen A, G. A. (2010). Creative place making:. National endowment for the arts,

McCabe, A. (2016). Place Partners: Place making consultancy. Retrieved from placepartners.com: http://www.placepartners.com.au/blog/space-vs-place-defining-difference

Mehrothra, R. (2007). The Static and the Kinetic, in 'Negotiating the Static and Kinetic Cities' published in A. Huyssen, ed., Urban Imaginaries, Durham, NC, 2007

MIT Department of Urban Studies and Planning, 2013. Places in the Making: New MIT Research on Place making Reveals the Power of Community Engagement in Design of Public Spaces. Retrieved from : http://www.prnewswire.com/news-releases/places-in-the-making-new-mitresearch-on-placemaking-reveals-the-power-of-community-engagement-in-design-of-publicspaces-228911941.html

Mills, P. (2014, November 10). Place making: How do we measure success? Retrieved from https://www.linkedin.com/pulse/20141110221830-147245611-placemaking-how-do-wemeasure-success

Montgomery, H. E. (1998). Nature: international weekly journal for science.

Pathinayake, A. D., Janaka Wijesundara (2015). Imaging Cities: Social perception and physical composition: the case study of Pettah, Colombo. Cities people places, international journal on urban environments, 47-60.

Planning, M. D. (2013). places in the making: New MIT research on place making reveals the power of community engagement in design of public spaces. CAMBRIDGE Mass.

Public spaces, P. f. (2016, February 19). Lighter, quicker and cheaper: 5 place making projects that inspire us. Retrieved from http://www.pps.org/blog/lightquickandcheap5placemakingprojectsthatinspireus/

R, R. (1992). Attachment to the ordinary landscape. In R. R, Place attachment (pp. 13-36). New York: Plenum Press.

Relph, E. (1976). Place and placelessness. London: Poin Limited, 207 Brondesbury Park.

Rousseeuw Carlo (2010) http://www.carlorousseeuw.be/portfolio-item/designing-kinetic-archite

Vazquez, Leonardo, Creative Placemaking: Integrating Community, Cultural and Economic Development (November 1, 2012). Available at

SSRN: https://ssrn.com/abstract=2474862 or http://dx.doi.org/10.2139/ssrn.2474862

Wyckoff, M. 2014. What placemaking style is right for you? WordPress.com. Retrieved from: https://communityplans.wordpress.com/tag/mark-wyckoff/ 